\title{
Review: \\ Biology of the commercially used sea urchin Tripneustes gratilla (Linnaeus, 1758) (Echinoidea: Echinodermata)
}

\author{
ABDUL HAMID A. TOHA ${ }^{1, \vartheta}$, SUTIMAN B. SUMITRO ${ }^{2}$, LUCHMAN HAKIM ${ }^{2}$, NASHI WIDODO ${ }^{2}$, \\ ROBI BINUR ${ }^{3}$, SUHAEMI ${ }^{4}$, AJI W. ANGGORO ${ }^{5}$ \\ ${ }^{1}$ Department of Fisheries, Faculty of Fisheries and Marine Sciences, Universitas Papua. Jl. Gunung Salju, Amban, Manokwari 98314, West Papua, \\ Indonesia. "email: hamid.toha@gmail.com \\ ${ }^{2}$ Department of Biology, Faculty of Mathematics and Natural Science, Universitas Brawijaya. Malang 65145, East Java, Indonesia \\ ${ }^{3}$ Department of Biology, Faculty of Mathematics and Natural Sciences, Universitas Papua. Manokwari 98314, West Papua, Indonesia \\ ${ }^{4}$ Department of Marine Science, Faculty of Fisheries and Marine Science, Universitas Papua. Manokwari 98314, West Papua, Indonesia \\ ${ }^{5}$ Indonesian Biodiversity Research Center (IBRC). Denpasar 80223, Bali, Indonesia
}

Manuscript received: 5 January 2017. Revision accepted: 1 June 2017.

\begin{abstract}
Toha AHA, Sumitro SB, Hakim L, Widodo N, Binur R, Suhaemi, Anggoro AW. 2017. Review: Biology of the commercially used sea urchin Tripneustes gratilla (Linnaeus, 1758) (Echinoidea: Echinodermata). Ocean Life 1: 1-10. Tripneustes gratilla is a species of sea urchin in shallow tropical waters. The species is economically and commercially important, has ecological value, and prospects as a biological control agent. It is considered as the commercially traded sea urchin. Overexploitation has caused a sharp decline in $T$. gratilla populations. Understanding biological aspects of $T$. gratilla is critical to the sustainable use of this resource in the future.
\end{abstract}

Keywords: Economically important, sea urchin Tripneustes gratilla

\section{INTRODUCTION}

Tripneustes gratillais sea urchin that is classified into kingdom Animalia, phylum Echinodermata, subphylum Echinozoa, class Echinoidea, subclass Euechinoidea, infraclass Carinacea, superordo Echinacea, ordo Camarodonta, infraordo Echinidae, superfamily Odontophora, family Toxopneustidae and genus Tripneustes (L. Agassiz 1841) (Kroh 2013). This species has distinct morphological characters (Toha et al. 2012) and various colours of spine and tube feet (Toha et al. 2015).T. gratilla has been categorized as primary herbivore (Lawrence and Agatsuma 2013, Unsworth et al. 2010)and its distribution is spread throughout the tropical waters of the Pacific and Indian Oceans (Kroh 2013).

Tripneustes gratilla (Linnaeus 1758) is economically important, due to its value in supporting small-scale fisheries and commercial trade, and is important ecologically (Williams 2002; Juinio-Meñes et al. 2001; Toha and Zain 2003; Toha 2006; Rahman et al. 2009; Toha et al. 2013). The sea urchin is also reported to own a prospect as a biological control agent (Stimson et al. 2007). It contains bioactive compounds useful for drug discoveries and pharmacological research (Takei et al. 1991; Nakagawa et al. 2003).

This paper covers comprehensive information on morphology, ecology, genetics, and conservation of this species. This we hope can provide important information to improve human welfare through the advancement of science development, technology, and environmental science.

\section{MORPHOLOGY}

Tripneustes gratilla is a round shaped sea urchin with different morphological characters. Its body surface has colourful short spine and tube feet (Toha et al. 2015)which can be moved for defense and locomotion. Its body (termed corona or test) is divided into an aboral and oral surface. Surfaces are separated by the ambitus (horizontal circle with large diameter). Each surface is ended with a circular opening covered by flat structures. There are two major openings in the corona, namely the peristome and periproct.T. gratilla is enclosed within a test like structure which consists of unified plates forming container where the species conduct its activities. Its testis a body part that determines its general morphology.

Tripneustes gratilla has different diameters and heights which are influenced by age and maturity. Some of them have 16.5-94.5 mm (Eklöf et al. 2009), $90 \mathrm{~mm}$ (Dafni and Tobol 1986), $97.9 \mathrm{~mm}$ (Fouda and Hellal 1990, and 120 $\mathrm{mm}$ (Coleman 1991) in diameter. And some of them have $155 \mathrm{~mm}$ (Baker 1968) heights. A maximum size of 160 $\mathrm{mm}$ test diameter is reported by Rahman et al. (2014). Test diameter observed in Indonesian waters ranges from 82.1 $\mathrm{mm}$ (Darsono and Sukarno 1993) and $100 \mathrm{~mm}$ (Radjab 1997). While Toha et al. (2012) recorded different sizes in area around Papua; Manokwari 56.97-77.92 mm; Saubeba 76-90.37 mm; Wasior 62.1-93.46 mm; Biak 50-87.5 mm and Serui $58-77 \mathrm{~mm}$. 


\section{HABITAT}

Tripneustes gratilla is known to inhabit different habitats (Lyimo et al. 2011) including: seagrass (Traer 1980, Calvin et al. 1985; Sammarco 1987; Sumitro et al. 1992; Aziz 1994; Susetiono 2004; Lyimo et al. 2011), algae, microalgae and macro algae (Ogden et al. 1989, Lyimo et al. 2011), sand with coral rubble, coral reef with reef flat (Lyimo et al. 2011; Lawrence and Agatsuma 2013).

However, in particular parts of the world T. gratilla is found to thrive in typically similar habitats. In Japan, $T$. gratilla is observed in coral reef intertidal and subtidal zones (Shigei 1970). In Okinawa, Japan this species is found in sandy reef, seaweed and algae areas on a reef flat (Shimabukuro 1991). In Papua New Guinea T. gratilla is observed in Thalassia hemprichii fields (Nojima and Mukai 1985, Mukai et al. 1987) while in the Philippines $T$. gratilla lives in sea grass areas dominated by Thalassia and Enhalus species and Sargassum sp. (Regalado et al. 2010). In Indonesia, this species lives in sandy and muddy bottom reef areas as well as sea grass and algae flourishing habitats (Toha et al. 2012). T. gratilla also is also occasionally found in sandy and muddy sand covered by sea grass at 0.5-20 meters depth (Radjab 2004).

Tripneustes gratilla can be observed up to a depth of 75 m (Lawrence and Agatsuma 2013), but according to Lawrence (2007) is most common in very shallow water on a variety of hard substrates between depths of 2 and 30 meters. Ogden et al. (1989) spotted this species along Hawaii living in coral reef areas with sandy lagoon covered with seagrass and algae. In general T. gratilla is found in the intertidal and littoral zone of coral reef ecosystems with sea temperature ranging from $23.6-26.8^{\circ} \mathrm{C}$ (Shigei 1970) in Japan. In Ambon, Indonesia, T. gratilla lives within 23.326.2 $2^{\circ}$ (Silahooy et al. 2013) and in Madagascar lives in 26-32 $\mathrm{C}$ ranges. However Toha et al. (2012) reported that this species is found within $30-31^{\circ} \mathrm{C}, 30-32^{\circ} \%$ salinity and pH 7.3-8 respectively, and Dafni (1992) reported survival below $15^{\circ} \mathrm{C}$. A report from Aqaba, Jordan, showed that this species could not move when transposed from 27 to $22^{\circ} \mathrm{C}$ (Lawrence 1973). This evidence indicates that there is an inactivity period during summer due to temperatures from 21-27 C (Dafni 1992). The highest latitude this species can be found is in South East Easter Island (Fell 1974) where sea temperature ranges from $17.5-24^{\circ} \mathrm{C}$ (DiSalvo et al. 1988).

\section{DISTRIBUTION}

Tripneustes gratilla is spread out throughout Western Pacific; Eastern Africa (Red Sea throughout Natal), Southern Islands (from Norfolk and Kermadec Island through Marquesas and Hawaii), Australia (from Port Jackson in eastern coast through Shark Gulf in western coast) and Southern Japan (including Bonin Islands) (Mortensen 1943). Lessios et al. (2003) and Lawrence and Agatsuma (2013) also reported that T. gratilla also spread extensively from Central Pacific through African Coast in the Indian Ocean. According to Shokita et al. (1991), T. gratilla is a sea urchin species found extensively along the Indian Ocean, Pacific and Indo Pacific, Indo Malaya including Australia, Japan, Eastern Coast of Africa and Eastern part of Hawaii (Kroh 2013).

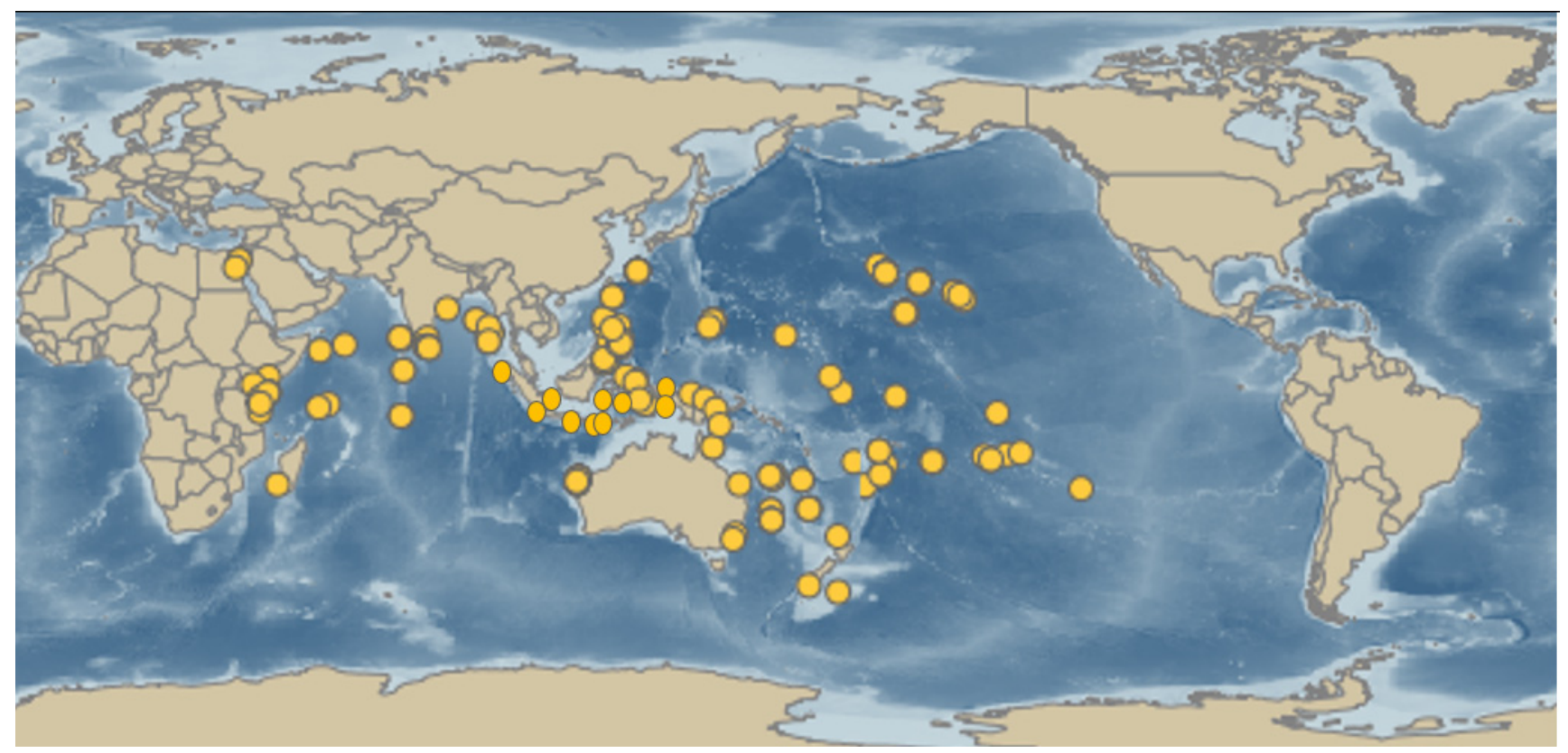

Figure 1. Distribution of sea urchin Tripneustes gratilla. Yellow dots indicate locations of T. gratilla (Modified from http://iobis.org/mapper/?taxon=Tripneustes\%20gratilla) 
In Indonesia, $T$. gratilla is spread out throughout all oceans including the eastern part of Indonesia (Aziz 1993) except the Arafura Sea (Clark 1946). T. gratilla is also found in Kema (Supono and Arbi 2010),Merah Cape (Lembeh Strait) (Susetiono 2004), Kapoposan Islands (Tuwo 1995), Spermonde Islands in Southern Sulawesi (Tuwo and Tresnati 1995), Morotai Beach in Northern Halmahera (Yusron 2006), Osi Islands in Western Seram Northern Maluku (Syam et al. 2002), Banda Neira (Andamari et al.1994), Tamedan in South East Maluku (Radjab 1997), Ambon (Silahooy et al. 2013), Buton in South East Sulawesi (Kasim 2009), Southern Lombok Beach (Aziz 1994), Nusa Dua Bali (Darsono and Sukarno 1993) and Balekambang-southern Malang (Sumitro et al. 1992). In addition, T. gratilla was also found in PadaidoPapua (Radjab 2004) and other Papua region such as Saubeba, Rendani Beach, Tanjung Pepaya, Nabire, Wasior, Biak (Toha and Fadli 2008; Toha et al. 2012). T. gratilla is spread out throughout all Papua-Indonesia with different local names (Toha and Zain 2003; Toha et al. 2014). T. gratilla was also found in Sanur-Bali, Tomia (Southeast Celebes), Jayapura (Papua), Palu, Donggala, Togian (middle Celebes).

\section{DENSITIES}

Density of $T$. gratilla varies over time and location. The lowest density was found during February 2006 and was increasing after two years (Edgar et al. 2009, Valentine and Edgar 2010). While in habitat covered sea grass and non sea grass density vary from $0.18 \pm 0.16$ ind.$/ \mathrm{m}^{2}$ to $0.54 \pm 0.21$ ind. $/ \mathrm{m}^{2}$ (Lyimo et al. 2011).

Mukai et al. (1987) observed the highest density of $T$. gratilla in less than one-meter depth in PNG where seagrass was found covering $80 \%$ of the observed areas. Alcoverro and Mariani (2002) observed average density of 1.5 ind. $/ \mathrm{m}^{2}$ in Mombasa Kenya. Uy et al. (2000) also found the same quantity in the Philippines. In southern Guimaras, Philippines, density ranges from $0.06-0.58$ ind. $/ \mathrm{m}^{2}$. A very high density is observed at Lucero, Bolinao, Pangasinan (Philippines) reaching 4.6 ind. $/ \mathrm{m}^{2}$ (Juinio-Meñes et al. 2008a). However, density of more 4 ind. $/ \mathrm{m}^{2}$ is also reported in few places in Lord Howe Island Marine Park (Valentine and Edgar 2010). In Hawaii and Red Sea $T$. gratilla density ranges from $2.9-4.4 / \mathrm{m}^{2}$ (Ogden et al.1989) and 50 ind. $/ \mathrm{m}^{2}$ (Dafni and Tobol 1986) respectively.

In Indonesia average density of this species varies in different locations. In the area around Osi Island the density is approximately0.754 $\pm 0.152 \mathrm{ind} / \mathrm{m}^{2}$ (Syam et al. 2002), while around Nusa Dua, Bali, Darsono and Sukarno (1993) reported the density was around $0.278 \mathrm{ind} / \mathrm{m}^{2}$, in Banda Neira around 2.83 ind $/ \mathrm{m}^{2}$ (Andamari et al.1994), and in Kema $0.84 \mathrm{ind} / \mathrm{m}^{2}$ (Supono and Arbi 2010).

Dotan (1990) stated that T. gratilla distribution around Aqaba Gulf follows no specific patterns time wise, which was not directly correlated with coverage and with high variation from time to time. High density of $T$. gratilla potentially affects abundance and distribution of macroalgae (Stimson 2007).

\section{BEHAVIOR}

Tripneustes gratilla typically lives in a group with patchy distribution patterns (Aziz 1993; Syam et al. 2002; Toha and Fadli 2008) to increase fertilization success (Levitan 2004). However, observations in Indonesia showed species distributions overlapping in one place with Toxopneustes pileolus, Mespilia globules, Temnotrema toreumaticus, and Pseudoboletia maculata (Aziz 1993) though with a tendency to live separately from other species.

This distribution, however, remains inconsistent; some individuals may be found to live separately from other individuals. Nojima and Mukai (1985) observed that some of $T$. gratilla have a tendency to live in couples, while populations that showed no individual-to-individual body contact were observed, even with high density (Shimabukuro 1991). Despite some observation in Madagascar finding that this species lives without a specific distribution pattern (Maharavo et al. 1994), Lawrence and Agatsuma (2013) reported that T. gratilla is often found in groups of three or four, often touching and even overlapping.

Maharavo et al. (1994) also reported that this species has a strong tendency to consume seagrass in one certain area before moving to another area with high density of sea grass. Nojima and Mukai (1985) found that these species move 1.3 meters/day haphazardly in seagrass beds. Another observation showed that $T$. gratilla aggregated in groups of 10-20 individuals in Madagascar and some were dominated by Thalassodendronciliatum (Alcoverro and Mariani 2002). T. gratilla has variable feeding habits, grazing nocturnally in Reunion Island (Lison deLoma et al. 1999) and diurnally in the Aqaba Gulf (Schumacher 1974).

Tripneustes gratilla exhibits cryptic covering behaviors, which serve as protection from predators, light exposure, and strong currents (Park and Cruz 1994). Ziegenhorn (2016) found that $T$. gratilla partially underneath rocks covered more, and with more algae than urchins totally underneath rocks. Ziegenhorn (2016) also found that $T$. gratilla had a distinct preference for cover that best protects them from UV radiation. Spine loss did not significantly affect urchin ability to cover, and urchins with removed spines still preferred opaque cover.

\section{DIET}

According to Rahim and Nurhasan (2016) seagrass and seaweed are the main diets for most sea urchin, and $T$. gratilla is the most well-known seagrass grazer (Lyimo et al. 2011). Information on feeding preference is important to study the effect of sea urchin to sea grass beds, which could also contribute important information to sustain management of sea grass ecosystems (Eklöf et al. 2008). 
Sea grass is mostly herbivore though some species also found to consume animal related materials (Lawrence 1975). According to de Loma et al. (2002), sea urchins feed on detritus material from seagrass as well as epiphytic and epibenthic micro and macroalgae, depending on variable factors including food availability and food preference (Lyimo et al. 2011).

The diet of $\mathrm{T}$. gratilla varies depending on habitat (Lawrence and Agatsuma 2013) and development stage. The larval stage requires an external source of food to allow juvenile benthic development. Pre-feeding embryos cannot directly eat phytoplankton and will grow epithelial cells on their surface that can detect food particles and decompose them into organic materials (Miner 2007). Early stage T. gratilla eat sessile diatoms while bigger individuals consume macroalgae (Sargassum spp., sea weed, and microflora) (Shimabukuro 1991).

Tripneustes gratilla is an omnivore that generally lives around the substrate and eats various types of algae, periphyton, and sea grass (Eklöf et al. 2008; Stimson et al. 2007; Tomascik 1997) as well as some crustaceans and mollusks (Radjab 1997). T. gratilla mostly consume sea grass of different types including Thalassodendron ciliatum, T. hemprichii, E. acoroides, Syringodim isoetifolium, Cymodocea rotundata, and other types of algae (Alcoverro and Mariani 2002; Kasim 2009; Lyimo et al. 2011). Laboratory scale experiment showed that $T$. gratilla preferred fresh brown algae Eckloniaradiata and dislike dry Ecklonia radiata, Sargassum linearifolium and Ulva lactuca (Dworjanyn et al. 2007; Cyrus et al. 2015).

Tripneustes gratilla in Hawaii was observed to consume macroalgae and sand containing macroflora (Ogden et al. 1989). While a further investigation in the Philippines showed the remnants of $T$. hemprichii, Halimeda, S. isoetifolium and rubles in their intestine, which shows that this may be their main source of food (Klumpp et al. 1993). However, the most dominant seaweed found in Madagascar in their intestine was $S$. isoetifolium (Vaïtilingon et al. 2003). In Papua New Guinea, T. gratilla consumes Cymodocea spp., E. acoroides, Halophila ovalis, S. isoetifolium, Thalassia hemprichii (Hattori et al. 1985). While in Kenya and Tanzanian it consumes T. ciliatum (Alcoverro and Mariani 2002) and mixes of $S$. isoetifolium, C. rotundata, Halodule uninervis, and T. hemprichii (Lyimo et al. 2011) respectively.

In Indonesia, $T$. gratilla eats variety of diets. In Bali it eats cuts of Ulva sp. and seagrass leaves (Darsono and Sukarno 1993). In Southeast Maluku it dominantly consumes E. acoroides, T. hemprichii and Caulerpa sp., Padina sp., Sargassum sp. T. gratilla was also reported to consume crustaceans (Copepoda, Amphipoda), mollusks (Gastropoda, Bivalvia) (Radjab 1997).

\section{REPRODUCTIVE CYCLE}

Tripneustes gratilla was observed to exhibit an annual reproductive cycle with variable intensities. T. gratilla has annual reproduction cycle which is influenced by various parameters including water temperature, day length and feeding activities (Vaïtilingon et al. 2005). Both male and female have a reproductive system that is divided into five different gonads. Despite being sexually dimorphic, it is difficult to distinguish males and females externally except if the gonad is in a mature stage. The mature female's gonad is bright orange while male's cement is bright yellow when mature. Gonad or called ROE is not only where egg or sperm production takes place but also the main food storage chamber (Bruce 1988).

Maximum gonad size can reach $10-15 \%$ of its net body weight (Fouda and Hellal 1990). Individual weight is 25$89 \mathrm{~g}$, while gonad weight varies between $0.203-1.925 \mathrm{~g}$, equal to $0.003-0.042 \%$ of the total body weight (Radjab et al. 2010). Gonad production increases when its size reaches $70 \mathrm{~mm}$ and has shown no observed decreasing pattern even when its size reaches $100 \mathrm{~mm}$. Muthiga (2005) reported that no significant correlation between gonad index and shell diameter while significant correlation is found between gonad weight and shell diameter.

Gonad production is influenced by diet. Male and female gonad production is a slight difference in output quantity (Lawrence 1987). However, this has never been thoroughly observed in the species. $T$. gratilla in sandy areas produce less sperm and egg than those living in sea grass (Jafari and Mahasneh 1984). Seasonally, most gonad peak production happens in spring (Tuason and Gomes 1979).

Gonad development occurs when its diameter reaches $50 \mathrm{~mm}$ at age less than one year (Dafni and Tobol 1986; Juinio-Menez et al. 1998). Mortensen (1943) reports that the gonophores open at an earlier state in some regions (gonads will already be present in those specimens). Gonad index increases at $70 \mathrm{~mm}$ size and remains at this index even when its diameter reaches $100 \mathrm{~mm}$. Gonad maturity levels can be explained through a few steps (Radjab 1997) and these are 0 (neutral), 1 (initiation), 2 (developed), 3 (early maturity), 4 (mature), 5 (spawning) and may vary depending on time of observation (Radjab 1997).

On a laboratory scale, early maturity occurred when the diameter reached $40 \mathrm{~mm}$ (Radjab et al. 2010) and first maturity occurred at 1.5 years old when shell diameter reached $60 \mathrm{~mm}$ (Trinidad-Roa 1989). Observation in Tamendan and Japan shown that gonad mature and spawn whole year around (Radjab 1997) and in the summer and fall respectively. In Bali gonad matures at diameter of 40 $\mathrm{mm}$ (Darsono and Sukarno 1993).

Spawning season varies in T. gratilla. In Taiwan, it happens in fall (Chen and Chang 1981), in the northern Red Sea (Pearse 1974) and Gulf of Aqaba (Kidron et al. 1972 ) in spring, summer through fall in Kenya (Muthiga 2005), and in fall at the Philippines (Chen and Chang 1981). While in Tamendan, South East Maluku, Indonesia spawning seasons was predicted between August and September and continues through to mid October (Radjab 1997). Other observations in the Philippines also show that T. gratilla may spawn throughout the year Tuason and Gomez (1979)

Eggs and sperms mature throughout the year in Solitary Island with peak production occurring in fall and winter. 
However, T. gratilla can only induce fertilization in fall (O'Connor et al. 1978). Gonad development phase is correlated with granule accumulation that started from March through June and declines in summer in Okinawa. This mature gonad is packed with eggs and spermson September (Shimabukuro 1991). Gametogenic activities occur throughout the year.

Pearse (1974) concluded that reproductive effort in $T$. gratilla doesn't correlate with temperature. Contrary to this, Chen and Chang (1981) stated that geographical variations in spawning correlate with temperature. Another observation reported that $T$. gratilla had mature and spawning phases each month, but an increased percentage of spawning phases observed in August and September (Radjab 1997).

\section{LIFE CYCLE AND GROWTH}

Sea urchins can live up to 100 years. Maximum age estimates acquired through growth zone in tiny skeleton bones in Lytechinus variegatus show that this species can live to maximum 4 years (Beddingfield and McClintock 2000), while the same method of measurement used for Strongylocentrotus intermedius resulted in a maximum age estimate of 10 years (Agatsuma 2001). Another method using $\mathrm{C}^{14}$ showed that $S$. franciscanus could live more than 100 years (Ebert and Southon 2003). T. gratilla, however, have been found to live relatively in a short time period. According to Lawrence (2001) and Shimabukuro (1991) $T$. gratilla can not live more than two years. Ebert (1982) also reported that $T$. gratilla could only live to maximum 1 year.

Tripneustes gratilla experiences few growth cycles in its life, with egg fertilization through to adult consisting of two cycles which include pre-adult (embryonic phase, larvae and juvenile) and the adult phase (Shokita et al. 1991). T. gratilla takes about two to five years to become a reproducing adult.

Generally sea urchins are of single sex with prevalence in spawning areas, and are able to disengage their sperms and eggs in the water column for fertilization (Levitan 2005, 2006; Rogers-Bennett 2007; Byrne et al. 2010). T. gratilla spawn once a year. Fertilized eggs will then turn into blastula and gastrula and subsequently grow into a planktonic prismatic stage. Inline with skeleton growth, the prismatic stage develops into larvae (echinopluteus or pluteus), which has a number of cilia, which may vary between 4 or 8 depending on the development stage (Byrne et al. 2008a, 2008b).

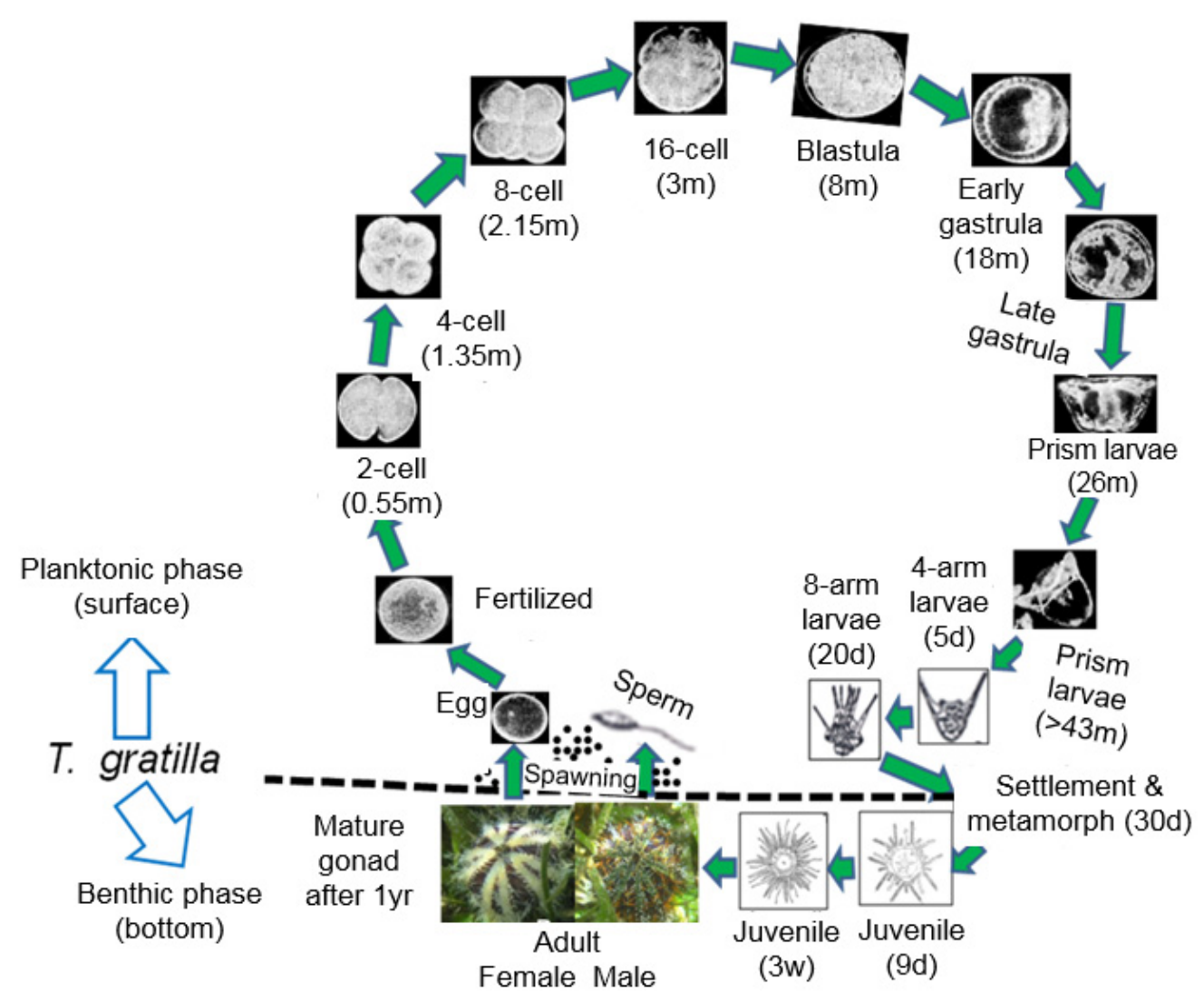

Figure 2. Life cycle of Tripneustes gratilla 
Laboratory scale observations in Japan show that larvae T. gratilla can develop completely within 20-30 days depending on temperature and food supplies (Shokita et al. 1991). However, an experiment in the Philippines showed that average larval duration was 42-52 days (Junio-Menez et al. 1998). Shokita et al. (1991) also reported that larval cycle (prismatic larvae, 4 and 8 arms larvae) in wild environments can persist for up to 25 days.

Laboratory observation shows that this species can attain complete metamorphosis within 18 days, while similar observation in Taiwan show this duration can take up to 30 days (Chen and Run 1988). Shimabukuro (1991) reported that diameter growth in $T$. gratilla could reach 60 $70 \mathrm{~mm}$. Similar observations in the Philippines (Bacolod and Dy 1986) and the Aqaba Gulf (Dafni 1992) reported that $T$. gratilla grew to $60 \mathrm{~mm}$ within five months of observation. Shell diameter growth in Tamedan, South East Maluku was on average $0.05 \mathrm{~mm} /$ day while growth in weight can reach $0.10 \mathrm{~g} /$ day (Radjab 1997).

Tripneustes gratilla found living in Southern Guimaras, the Philippines can reach $60 \mathrm{~mm}$ within 8 months (Regalado et al. 2010), though similar studies in the same place a year before showed that the same diameter was reached within 10 months (Beldia et al. 2003). The difference in growth parameters shows that habitat condition and diet may affect growth level and maximum size in T. gratilla (Regalado et al. 2010, Juinio-Meñes et al. 2008). Shimabukuro (1991) also reported that growth could also slow down when this species experiences stress. Furthermore, it was reported that the growth could escalate when this species changes its diet from sessile diatoms to macroalgae. Individual diameter can also reach $10 \mathrm{~mm}$ in June and 60-70 $\mathrm{mm}$ in November.

\section{RECRUITMENT}

According to Ebert (1982) recruitment in this species can be patchy due to random movement of this species throughout the area it inhabits. This finding is supported by Dafni and Tobol (1986) who found random areas of recruitment in the Red Sea. The random areas recruitment success is related to its ability to live in different habitats including sand and sea grass beds, lagoon, coral reefs and the intertidal zone. According to Juinio-Meñes et al. (2008b) recruitment success in farming scale is influenced by biophysical and local management intervention.

Recruitment reaches a peak in November in the Philippines with a smaller peak in March (Bacolod and Dy 1986). Another observation in the same place also shows that this species mainly recruits in April and May. Observations from Papua New Guinea suggest that recruitment only happens once in a year (Mukai et al. 1987). However the same observations during 1980-1981 by (Dafni 1992; Dafni and Tobol 1986) shown that $T$. gratilla with less than $10 \mathrm{~mm}$ in size are found in large quantities in January through February, May through June and in August (Dafni 1992; Dafni and Tobol 1986).

\section{MORTALITIES}

Pacific and Atlantic population of Tripneustes have shown a high mortality and fecundity rate with also fast individual and population growth (Lawrence and Agatsuma 2013). Mortality in T. gratilla is influenced by several factors including seasonal rains and bad weather (Vaïtilingon et al. 2005), decreased recovery (Ebert 1982), succession (Dafni 1992; Dafni and Tobol 1986), entrapment in shallow water (Shimabukuro 1991), habitat alteration and predation (Regalado et al. (2010), natural death (Juinio-Menez 2008) and many other unknown factors (Eklöf et al. 2009).

Regalado et al. (2010) reported that mortality in $T$. gratilla can reach 99.3\%. Juinio-Menez (2008) also reported that natural mortality in different sites in Luzon Northwestern and Central Philippines varies from 91-96\% and $99 \%$ respectively. High mortality in Hawaii, Kenya, Seychelles, and Israel can be caused by low recovery capacity after a one-year period (Ebert 1982). Dafni (1992) and Dafni and Tobol (1986) also reported that mass mortality in Eilat typically happens twice during winter succession. However, low mortality is observed during rainy seasons on shallow reef flats in Okinawa (Shimabukuro 1991).

\section{PREDATORS}

Tripneustes gratilla is hunted by humans for its delicious gonads, and other predators include parrotfish, triggerfish and pufferfish (Mahon and Parker 1999), which also consume its gonads and shell contents. Specifically, in sea grass areas, T. gratilla is hunted by Cassissp (Tertsching 1989). However, the main predators of $\mathrm{T}$. gratilla in protected areas and hard, rough substrates are sea stars (Protoreaster linki) (Shears and Babcock 2002, Bonaviri et al. 2009; Eklöf et al. 2009). Eklöf et al. (2009) also found that $T$. gratilla has many other predators including Asteroidea, Gastropoda, Balistidae and Labridae.

\section{COMMUNITIES}

According to Valentine and Edgar (2010), T. gratilla has a specific role as an ecosystem engineer. High density can cause a significant decrease in algal coverage including red and brown algae. Encrusting coralline algae coverage increases with higher densities of T. gratilla (Bacolod and Dy 1986). T. gratilla is also a pest in sea grass farming though recovery process is not entirely affected it. Hyperabundant populations of $T$. gratilla have been observed to overgraze complete seagrass beds of primarily Thalassodendron ciliatum on the Kenyan coast (Alcoverro and Mariani 2002; Zanre and Kithi 2004; Uku and Björk 2005). 


\section{GENETIC}

More than 274 nucleotide sequences for $T$. gratilla are available in the NCBI database (http: //www.ncbi.nlm.nih.gov/nuccore). Including the full $T$. gratilla mitochondrial genome ranging from 15720-15725 bp. Available sequences include many samples from COI partial group (more than 220 partial sequences). There are various uses for nucleotide sequences, such as for morphological and molecular phylogeny (Littlewood and Smith 1995), genetic patterns (Liggins et al. 2014), marker organization (Carlon and Lippe 2007), primary design for barcoding (Hoareau and Boissin 2010), phylogeny and expression (Gibbons et al. 1994), mtDNA phylogeny (Zigler and Lessios 2003), retrovirus-like element (Springer et al. 1991), evolutionary history of larval skeleton morphology (Kinjo et al. 2008), and others.

Studies on molecular genetics of the T. gratilla show that high gene flow up to more than hundreds of kilometers is a standard characteristic of all sea urchin species possessing a planktonic larval stage (Lessios et al. 2001, Liggins et al. 2014 ), and similar patterns are found from $T$. gratillain Indonesian waters (Toha et al. 2014).

\section{CONSERVATION}

Tripneustes gratilla has not yet been assessed for the IUCN Red List. However, like other sea urchins, it has biological characteristics that make it susceptible to overexploitation. In general, sea urchins mostly prefer particular habitats, and their slow movement restricts their distribution and may cause them to be vulnerable to local extinction. In general, sea urchin fisheries do not have any management system or local restrictions. Sea urchins are also a target for biotechnology and a variety of biologically active compounds has been isolated from the sea urchin species. Target species for these purposes is not specific and there is some financial benefit to local communities. It is necessary to regulate this industry to ensure maintain viable populations (Micael et al. 2009).

Conservation is important in order to protect $T$. gratilla stocks. Several steps conducted for echinoid conservation in France (Mediterranean and Atlantic), Ireland, Iceland, South Korea and Philippines and China are: entry limitation (moratorium) followed with active programs to reduce latent businesses, resources survey at various complexity levels, to use an annual total fishing permit based on resources analysis, zonal and regional management towards rotational harvest points, and to use a minimum legal size (Williams 2002).

In the Philippines, Marine Science Institute has opened a $T$. granilla hatchery at the reef flats of Bolinao, Pangasinan. In South Korea, on a coastal scale, this is done through village collaborations that decide how many people have access and when to do. Vessel permit restrictions are also a sea urchin fisheries management strategy in South Korea. Sea urchin fisheries in Russia are set by regulating total allowable catch based on fisheries free-survey and fisheries information analysis. Minimum size permits and fishing season are also implemented to protect their spawning.

In New Zealand, sea urchin fishery is a non-quota fishery and managed through various permits and season and fishing ground closures. On the other hand, Tasmanian sea urchin fishery has been regulated through moratorium strategy for new entrants in 1990s and the permit cannot be moved. In 2002, Tasmania conducted a competition of total allowable catch, in which it was divided into zones and the total allowable catch was used to encourage management and regulation. In New South Wales, the sea urchin fishery used entry limitations through removable permits. Area closures are applied to restrict access.

The present conservation mechanism should be integrated and consistently set up on a global scale. Furthermore, sea urchin fisheries need an ecosystem approach through increase in information exchanges between government institutions, NGOs, and academician, and inter-stakeholder dialogues, including industries and sea urchin resources communities. Development and integration of several suggestions for size and spatial scale difference considerations (local, regional and global) will allow sustainability in using sea urchin species as resources. There is also clear necessity to raise our biological knowledge on the target species to promote that group diversity is maintained (Micael et al. 2009).

\section{ACKNOWLEDGEMENTS}

The authors thank the University of Papua and Higher Education of Republic Indonesia for funding the National Strategic Research (No. 235/H42/KU/2009). The authors thank the anonymous reviewers for their comments which improved the manuscript.

\section{REFERENCES}

Agatsuma Y. 2001. Ecology of Strongylocentrotus intermedius. In: Lawrence JM. (ed.) Edible Sea Urchins: Biology and Ecology. Developments in Aquaculture and Fisheries Science, Vol. 32. Elsevier, Amsterdam.

Alcoverro T, Mariani S. 2002. Effects of sea urchin grazing on seagrass (Thalassodendron ciliatum) beds of a Kenyan lagoon. Mar Ecol Prog Ser 226: 255-263.

Andamari R, Zubaidi T, Subagyo. 1994. Beberapa aspek biologi bulu babi Tripneustes spp. di Pulau Neira, Kepulauan Banda. Jurnal Penelitian Perikanan Laut 94: 23-34.

Aziz A. 1993. Beberapa catatan tentang perikanan bulu babi. Oseana 18 (2): 65-75.

Aziz A. 1994. Aktivitas grazing bulu babi jenis Tripneustes gratilla pada padang lamun di pantai Lombok Selatan. Dalam: Kiswara W, Mosa MK, Hutomo M. (eds.). Struktur Komunitas Biologi Padang Lamun di Pantai Selatan Lombok dan Kondisi Lingkungannya. P3O-LIPI, Jakarta.

Bacolod PT, Dy DT. 1986. Growth, recruitment pattern and mortality rate of sea urchin, Tripneustes gratilla Linnaeus, in a seaweed farm at Danahon Reef, Central Philippines. Philippines Sci 23: 1-14.

Baker AN. 1968. The echinoid fauna of Northeastern New Zealand. Trans Roy Soc N Z Zool 8: 239-245.

Beddingfield SD, McClintock JB. 2000. Demographic characteristics of Lytechinus variegatus (Echinoidea: Echinodermata) from three habitats in a north Florida Bay, Gulf of Mexico. Mar Ecol 21: 17-40.

Beldia II, Evano NP, Campos WL, Santillan AS, Bitoon-On JB, Jalandoni PB. 2003. Population parameter estimates of two seagrass associated 
sea urchins Echinodermata in Southern Guimaras, Philippines. Preliminary findings. Philippines Sci 40: 122-142.

Bonaviri C, Vega FT, Badalamenti F, Gianzugga P, Di Lorenza M, Riggio S. 2009. Fish versus starfish predation in controlling sea urchin populations in Mediterranean rocky shores. Mar Ecol Prog Ser 382: 129-138.

Bruce CA. 1988. Sea urchins. Infofish Intl 3: 32-34.

Byrne M, Prowse TAA, Sewell MA, Dworjanyn S, Williamson JE, Vaïtilingon D. 2008a. Maternal provisioning for larvae and larvae provisioning for juveniles in the toxopneustid sea urchin Tripneustes gratilla. Mar Biol 155: 473-482.

Byrne M, Sewell MA, Prowse TAA. 2008b. Nutritional ecology of sea urchin larvae: influence of endogenous and exogenous nutrition on Echinops luteal growth and phenotypic plasticity in Tripneustes gratilla. Funct Ecol 22: 643-648.

Byrne M, Soars NA, Ho MA, Ong E, McElroy D, Selvakumaraswamy P, Dorjanyn SA, Davis AR. 2010. Fertilization in a suite of coastal marine invertebrates from SE Australia is robust to near-future ocean warming and acidification. Mar Biol 157: 2061-2069.

Calvin J, Hedgepeth E. Ricketts. 1985. Between Pacific Tides: 5th ed. Stanford University Press, USA.

Carlon DB, Lippe C. 2007. Eleven new microsatellite markers for the tropical sea urchin Tripneustes gratilla and cross-amplification in Tripneustes ventricosa. Mol Ecol Notes 7 (6): 1002-1004.

Chen CP, Chang K-H. 1981. Reproductive periodicity of the sea urchin, Tripneustes gratilla (L.) in Taiwan compared with other regions. Intl J Invert Reprod 3: 309-319.

Chen C-P, Run J-Q. 1988. Some aspects on rearing larvae and larval development of Tripneustes gratilla (L.) (Echinodermata: Echinoidea). Bull Inst Zool Academia Sinica 27 (3): 151-157.

Clark HL. 1946. The echinoderm fauna of Australia. The Carnegie Institution of Washington Publication 566: 1-567.

Coleman N. 1991. Encyclopedia of Marine Animal. Bandford, London.

Cyrus MD, Bolton JJ, Macey BM. 2015. The role of the green seaweed Ulva as a dietary supplement for full life-cycle grow-out of Tripneustes gratilla. Aquaculture 446: 187-197.

Dafni J, Tobol R. 1986. Population structure patterns of a common Red sea echinoid (Tripneustes gratilla elatensis). Israel J Zool 34: 191204

Dafni J. 1992. Growth rate of the sea urchin Tripneustes gratilla elatensis Israel J Zool 38: 25-33.

Darsono P, Sukarno. 1993. Beberapa aspek biologi bulubabi Tripneuste gratilla (Linnaeus) di Nusa Dua, Bali. Osenologi di Indonesia 26: 1325

DiSalvo LH, Randall JE, Cea A. 1988. Ecological reconnaissance of the Eastern Island sublittoral marine environment. Nat Geogr Res 4: 451473.

Dotan A. 1990. Distribution of regular sea urchin on coral reefs near the south-eastern tip of the Sinai Peninsula, Red Sea. Israel J Zool 37: 15 29.

Dworjanyn SA, Pirozzi I, Liu W. 2007. The effect of the addition of algae feeding stimulants to artificial diets for the sea urchin Tripneustes gratilla. Aquaculture 273 (4): 624-633.

Ebert TA, Southon JR. 2003. Red sea urchins (Strongylocentrotus franciscanus) can live over 100 years: confirmation with A-bomb ${ }^{14}$ carbon. Fish Bull 101 (4): 915-922.

Ebert TA. 1982. Longevity, life history, and relative body wall size in sea urchins. Ecol Monogr 52: 353-394.

Edgar GJ, Davey A, Mawbey RB, Parsons K. 2009. Biogeographical and ecological context for managing threats to coral and rocky reef communities in the Lord Howe Island Marine Park, south-western Pacific. Aquat Conserv. DOI: 10.1002/agc.1075

Eklöf JS, Fröcklin, S, Lindvall A, Stadlinger N, Kimathi A, Uku JN, McClanahan TR. 2009. How effective are MPAs? Predation contro and 'spill-in effect' in seagrass-coral reef lagoons under contrasting fishery management. Mar Ecol Prog Ser 384: 83-96.

Eklöf S, de la Torre-Castro M, Gullström M, Uku J, Muthiga N, Lyimo T, Bandeira SO. 2008. Sea urchin overgrazing of seagrasses: A review of current knowledge on causes, consequences, and management. Estuar Coast Shelf Sci 79 (4): 569-580

Fell FJ. 1974. The echinoids of Easter Island (Rapa Nui). Pac Sci 28: $147-$ 158.

Fouda MM, Hellal AM. 1990. Reproductive biology of Tripneustes gratilla (L) from Gulf of Aqaba and northern Red Sea. In: Ridder C, Lahaye M, Jangoux M (eds) Echinoderm Research. Balkema, Rotterdam.
Gibbons BH, Asai DJ, Tang WJ, Hays TS, Gibbons IR. 1994. Phylogeny and expression of axonemal and cytoplasmic dynein genes in sea urchins. Mol Biol Cell 5 (1): 57-70.

Hattori A, Aioi K, Iizumi H, Koike I, Mukai H, Nishihira M, Nojima S, Yokohama Y. 1985. Studies on dynamics of the biological community in tropical seagrass ecosystems in Papua New Guinea. Report of the Study Supported by the Grant-in-Aid of Ministry of Education, Culture and Science, Japan.

Hoareau TB, Boissin E. 2010. Design of phylum-specific hybrid primers for DNA barcoding: addressing the need for efficient COI amplification in the Echinodermata. Mol Ecol Resour 10 (6): 960967.

Jafari RD, Mahasneh DM. 1984. The effect of seagrass grazing on the sexual maturity of the sea urchin Tripneustes gratilla in the Gulf of Aqaba (Jordan). Am'man al'J'ami'ah al'Urdun'iyah 14: 127-136.

Juinio-Meñes MA, Bangi HG, Malay MCD, Pastor DS. 2008a. Enhancing the recovery of depleted Tripneustes gratilla stocks through grow-out culture and restocking. Rev Fish Sci 16: 35-43.

Juinio-Meñes MA, Bangi HG, Malay MCD. 2008. Effect of type of feed, stocking density and grow-out site on gonad index, growth and survivorship of cultured sea urchin (Tripneustes gratilla). Philippines Agric Sci 91 (4): 439-449

Juinio-Meñes MA, Macawaris ND, Bangi HGP. 1998. Community-based sea urchin (Tripneustes gratilla) grow-out culture as a resource management tool. Can Spec Publ Fish Aquat Sci 125: 393-399.

Juinio-Meñes MA, Malay MC, Bangi HGP. 2001. Sea Urchin grow-out Culture. Coastal Resource Management Tool. Marine Environment Resources Foundation, Inc. The Marine Science Institute. University of the Philippines, Diliman, Quezon City.

Juinio-Meñes MA, Pastor D, Bangi HG. 2008b. Indications of recruitment enhancement in the sea urchin Tripneustes gratilla due to stock restoration effect. Proceedings of the $11^{\text {th }}$ International Coral Reef Symposium, Ft. Lauderdale, Florida, 7-11 July 2008. 1018-1021.

Kasim M. 2009. Grazing activity of the sea urchin Tripneustes gratilla in tropical seagrass beds of Buton Island, Southeast Sulawesi, Indonesia. J Coast Dev 13: 19-27.

Kidron J, Fishelson L, Moav B. 1972. Cytology of an unusual case of hermaphroditic gonads in the tropical sea urchin Tripneustes gratilla from Eilat (Red Sea). Mar Biol 14: 260-263.

Kinjo S, Shirayama Y, Wada H. 2008. Evolutionary history of larval skeletal morphology in sea urchin Echinometridae (Echinoidea: Echinodermata) as deduced from mitochondrial DNA molecular phylogeny. Evol Dev 10 (5): 632-641.

Klump DW, Salita-Espinosa JT, Fortes MD. 1993. Feeding ecology and trophic role of sea urchins in a tropical seagrass community. Aquat Bot 45: 205-229.

Kroh A. 2013. Tripneustes gratilla. In: Kroh A, Mooi R. 2017. World Echinoidea Database. Accessed through: World Register of Marine Species at http: //www.marinespecies.org/aphia.php? $\mathrm{p}=$ taxdetails $\& \mathrm{id}=212453 \quad$ on 2017-06-03.

Lawrence JM, Agatsuma Y. 2013. Tripneustes. In: Lawrence JM (ed.). Sea Urchins: Biology and Ecology, 3rd ed. Academic Press, Croydon, UK.

Lawrence JM. 1973. Temperature tolerances of tropical shallow-water echinoids (Echinodermata) at Eliat (Red Sea). Israel J Zool 22: 142150.

Lawrence JM. 1975. On the relationships between marine plants and sea urchins. Oceanography and Marine Biology Ann Rev 13: 213-286.

Lawrence JM. 1987. A functional biology of echinoderms. The Johns Hopkins University Press, Baltimore.

Lawrence JM. 2001. The edible sea-urchins. In: Lawrence JM. (ed.) Edible Sea Urchins: Biology and Ecology. Developments in Aquaculture and Fisheries Science, Vol. 32. Elsevier, Amsterdam.

Lawrence JM. 2007. Edible Sea Urchins: Biology and Ecology. Elsevier, Boston

Lessios HA, Kane J, Robertson DR. 2003. Phylogeography of the pantropical Sea Urchin Tripneustes: Contrasting patterns of Population Structure Between Oceans. Evolution 57 (9): 2026-2036.

Lessios HA, Kessing BD, Pearse JS. 2001. Population structure and speciation in tropical seas: phylogeography of the sea urchin Diadema. Evolution 55 (5): 955-975.

Levitan DR. 2004. Density-dependent sexual selection in external fertilizers: Variances in male and female fertilization success along the continuum from sperm limitation for sexual conflict in the sea urchin Strongylocentrotus franciscanus. Am Nat 164 (3):- 
Levitan DR. 2005. The distribution of male and female reproductive success in a broadcast spawning marine invertebrate. Integrat Compar Biol 45: 848-855.

Levitan DR. 2006. The relationship between egg size and fertilization success in broadcast-spawning marine invertebrates. Integrat Compar Biol 46: 298-311.

Liggins L, Gleeson L, Riginos C. 2014. Evaluating edge-of-range genetic patterns for tropical echinoderms, Acanthaster planci and Tripneustes gratilla, of the Kermadec Islands, Southwest Pacific. Bull Mar Sci 90 (1):. 379-397.

Lison de Loma T, Harmelin-Vivien M, Conand C. 1999. Diet feeding rhythm of the sea urchin Tripneustes gratilla (L) on a coral reef at La Reunion, Indian Ocean. In: Candia Carnevali MD, Bonasoro F (eds) Echinoderm Research 1998. Balkema, Rotterdam.

Littlewood DT, Smith AB. 1995. A combined morphological and molecular phylogeny for sea urchins (Echinoidea: Echinodermata). Phil Trans R Soc Lond B Biol Sci 347: 213-234.

Lyimo TJ, Mamboya, F, Hamisi M Lugomela C. 2011. Food preference of the sea urchin Tripneustes gratilla (Linnaeus, 1758) in tropical seagrass habitats at Dar es Salaam, Tanzania. J Ecol Nat Environ 3 (13): 415-423.

Maharavo J, Marie-Berthe R, Bernard AT. 1994. Food preference of Tripneustes gratilla (L) (Echinoidea) on fringing reef flats off the NW Coast of Madagascar (SW Indian Ocean). Echinoderms through time: proceedings of the eighth International Echinoderm Conference. CRC Press, UK.

Mahon R, Parker C. 1999. Barbados sea eggs, past, present, future. Fisheries Management Plan, Public Information Document No. 1., Fisheries Division, Ministry of Aquaculture and Rural Development, Barbados.

Micael J, Alves MJ, Costa AC, Jones MB. 2009. Exploitation and conservation of echinoderms. Oceanogr Mar Biol 47: 191-208.

Miner BG. 2007. Larval feeding structure plasticity during pre-feeding stages of echinoids: not all species respond to the same cues. J Exp Mar Biol Ecol 343: 158-165.

Mortensen T. 1943. A monograph of the Echinoidea. 11.2. Camarodonta I. Copenhagen. CA Reitzel, Copenhagen.

Mukai, H, Nishihira M, Nojima S. 1987. Distribution and biomass of predominant benthic animals. In: Hattori A (ed.). Studies on dynamics of the biological community in tropical seagrass: ecosystem in Papua New Guinea: the second report. Ocean Research Institute, Tokyo.

Muthiga NA. 2005. Testing for the effects of seasonal and lunar periodicity on the reproduction of the edible sea urchin Tripneustes gratilla (L) in Kenyan coral reef lagoons. Hydrobiologia 549: 57-64.

Nakagawa H, Tanigawa T, Tomita K, Tomihara Y, Araki Y, Tachikawa E. 2003. Recent studies on the pathological effects of purified sea urchin toxins. J. toxicology: Toxin Rev 22 (4): 633-649.

Nojima S, Mukai H. 1985. A preliminary report on the distribution pattern, daily activity and moving pattern of a seagrass grazer, Tripneustes gratilla (L) (Echinodermata: Echinoidea), in Papua New Guinean seagrass beds. Spec Publ Mukaishima Mar Biol Sta 1989 173-183.

O’Connor C, Riley G, Lefebvre 5, Bloom D. 1978. Environmental influences on histological changes in the reproductive cycle of four New Sout Wales sea urchin. Aquaculture 15: 1-17.

Ogden N, Ogden SC, Abbot IA. 1989. Distribution, abundance, and food of sea urchins on a leeward Hawaiian reef. Bull Mar Sci 45: 539-549.

Park I, Cruz C. 1994. Masking behavior and distribution of the tropical sea urchin Tripneustes gratilla. Biol Geomorphol Trop Is 4: 22-47.

Pearse JS. 1974. Reproductive patterns of tropical reef animals: three species of sea urchins. Proc $2^{\text {nd }}$ Int Coral Reef Symp, pp 235-240.

Pena MH, Oxenford HA, Parker C, Johnson A. 2010. Biology and fishery management of the white sea urchin, Tripneustes ventricosus, in the eastern Caribbean FAO Fisheries and Aquaculture Circular. No. 1056. FAO, Rome.

Radjab AW, Khouw AS, Mosse JW, Uneputty PA. 2010. Pengaruh pemberian pakan terhadap pertumbuhan dan reproduksi bulu babi (Tripneustes gratilla) di laboratorium. Oseanologi dan Limnologi di Indonesia 36 (2): 243-258

Radjab AW. 1997. Pertumbuhan dan reproduksi bulubabi Tripneustes gratilla di perairan Tamedan, Maluku Tenggara. Prosiding Seminar Kelautan LIPI-UNHAS ke 1. Ambon, Maret 1998.

Radjab AW. 2004. Sebaran dan kepadatan bulu babi di perairan Kepulauan Padaido, Biak Irian Jaya. Dalam: Setyawan WB, Witasari Y, Arifin Z, Ongkosongo OSR, Biro S (eds). Pros Sem Laut Nasional III, Jakarta.
Rahim SAKA, Nurhasan R. 2016. Status of sea urchin resources in the East Coast of Borneo. J Mar Biol. Article ID 6393902, 8 p. DOI: $10.1155 / 2016 / 6393902$

Rahman MA, Arshad A, Yusoff FMd. 2014. Sea Urchins (Echinodermata: Echinoidea): Their Biology, Culture and Bioactive Compounds. International Conference on Agricultural, Ecological and Medical Sciences (AEMS-2014) July 3-4, 2014 London, UK. DOI: 10.15242/IICBE.C714075

Rahman S, Tsuchiya M, Uehara T. 2009. Efects of temperature on hatching rate, embryonic development and early larval survival of the edible sea urchin, Tripneustes gratilla. Biologia 64 (4) 768-775.

Regalado JM, Campos WL, Santillan AS. 2010. Population biology Tripneustes gratilla (Linnaeus) (Echinodermata) in seagrass beds of Southern Guimaras, Philippines. Science Diliman 22 (2): 41-49.

Rogers-Bennett L. 2007. The ecology of Strongylocentrotus franciscanus and Strongylocentrotus purpuratus. In: Lawrence JM. (ed). Edible Sea urchins: Biology and Ecology. Elsevier, Amsterdam.

Sammarco PW. 1987. A comparison of some ecological processes on coral reefs of the Carribean and the Great Barrier Reef. Unesco Rep Mar Sci 46: 127-166.

Schumacher H. 1974. On the conditions accompanying the first settlement of corals on artificial reefs with special reference to the influence of grazing sea urchins (Eilat, Red Sea). Proc 2 Intl Coral Reef Symp 1: 257-267.

Shears NT, Babcock RC. 2002. Marine reserves demonstrate top-down control of community structure on temperate reefs. Oecologia 132: 131-142.

Shigei M. 1970. Echinoids of the Bonin Islands. J Fac Sci Univ Tokyo 12: $1-22$.

Shimabukuro S. 1991. Tripneustes gratilla (sea urchin). In: Shokita S, Kakazu K, Tomori A, Toma T (eds), Yamaguchi M (English ed) Aquaculture in Tropical Areas. Midori Shobo Co, Ltd, Tokyo.

Shokita S, Kakazu K, Tomori A, Toma T (eds). 1991. Aquaculture in Tropical Areas. Midori Shobo Co. Ltd., Tokyo, ]apan.

Silahooy VB, Toha AH, Hakim L, Widodo N. 2013. Spatial distribution of Tripneustes gratilla on Ambon Island. J Trop Life Sci 3 (3): 177181.

Springer MS, Davidson EH, Britten, RJ. 1991. Retroviral-like element in a marine invertebrate Proc Natl Acad Sci USA 88: 8401-8404.

Stimson J, Cunha T, Philippoff J. 2007. Food preferences and related behavior of the browsing sea urchin Tripneustes gratilla (Linnaeus) and its potential for use as a biological control agent. Mar Biol 151: 1761-1772.

Sumitro SB, Wijarni U, Pramana A, Soewondo A, Samino S. 1992. Inventarisasi jenis, habitat dan tingkah laku hewan bulu babi (Sea Urchin) di Jawa Timur serta usaha pemijahan dan pengembangan teknik kultur embrio. Jurnal Universitas Brawijaya 4 (2): 50-58.

Supono, Arbi UY. 2010. Struktur komunitas ekhinodermata di padang lamun Perairan Kema, Sulawesi Utara. Oseanologi dan Limnologi di Indonesia 36 (3): 329-342

Susetiono. 2004. Fauna padang/lamun Tanjung Merah, Selat Lembeh. Pusat Penelitian Oseanografi-LIPI. Jakarta.

Syam AR, Edrus IN, Andamari R. 2002. Populasi dan tingkat pemanfaatan bulu babi (Echinoidea) di Padang Lamun Pulau Osi, Seram Barat, Maluku Tengah. JPPI Edisi Sumber Daya dan Penangkapan 8 (4): 31-37.

Takei N, Nakagawa H. Kimura A, Endo K. 1991. A toxin substance from sea urchin Toxopneustes pileolus induces histamine release from rat peritoneal mast cells. Inflam Res 32 (3-4): 224-228.

Tertschning WP. 1989. Diet activity patterns and foraging dynamics of the sea urchin Tripneustes ventricosus in a tropical seagrass community and a reef environment (Virgin Islands). Mar Ecol 10 (1): 3-21.

Toha AHA, Binur R, Suhaemi, Lutfi, Hakim L, Widodo N, Sumitro SB. 2014. Genetic aspects of the commercially used sea urchin Tripneustes gratilla. J Biol Res 20 (2): 12-17.

Toha AHA, Fadli Z. 2008. Keragaman spesies bulu babi (Echinoidea) di Perairan Manokwari. Jurnal Perikanan dan Kelautan. Berkala Ilmiah Penelitian Perikanan dan Kelautan 4 (1): 13-30.

Toha AHA, Sumitro SB, Hakim L, Widodo. 2012. Kondisi habitat bulu babi Tripneustes gratilla (Linnaeus, 1758) di Teluk Cenderawasih. Berk Penel Hayati 17 (2): 139-145.

Toha AHA, Sumitro SB, Widodo, Hakim L. 2015. Color diversity and distribution of Sea Urchin Tripneustes gratilla in Cenderawasih Bay ecoregion of Papua, Indonesia. Egyptian J Aquat Res 41 (3): 273-278.

Toha AHA, Zain S. 2003. Prospek pemanfaatan gonad bulu babi sebagai bahan pangan alternatif selain ikan. Prosiding Lokakarya Nasional 
Pendayagunaan Pangan Spesifik Lokal Papua, Jayapura, 2-4 Desember 2003.

Toha AHA. 2006. Manfaat bulu babi (Echinoidea), dari sumber pangan sampai organisme hias. Jurnal Perikanan dan Ilmu Perairan 13 (1): $77-82$.

Toha AHA, Sumitro SB, Hakim L. 2013. Keanekaragaman dan Konservasi Bulu Babi. Penerbit Galaxy Science, Malang.

Tomascik T. 1997. The Ecology of the Indonesian Seas (Part 2). Tuttle Publishing, UK.

Traer K. 1980. The consumption of Posidonia oceanica Delile by Echinoids at the Isle of Ischia. In: Jangoux M (ed.) Echinoderms: Present and past. Proc. 1st European Echinoderm Conf., Bruxelles, 3 8 Sept. 1979 A.A. Balkema, Rotterdam.

Trinidad-Roa MJ. 1989. Mariculture potential of giant clams and sea urchin in the Lingayen Gulf Area. In: Toward sustainable development of the coastal resources of Lingayen Gulf, Philippines. Philippine Council for Aquatic and Marine Research and Development, Manila.

Tuason AY, Gomez ED. 1979. The reproductive biology of Tripneustes gratilla Linnaeus (Echinoidea: Echinodermata) with some notes on Diadema setosum Leske. In: Proceedings of the International Symposium on Marine Biogeography and Evolution in the Southern Hemisphere, Auckland, NZ, July 17-20, 1978, Vol. 2. NZ Dept. of Scientific and Industrial Research, NZ.

Tuwo A, Tresnati J. 1995. Studi pendahuluan aspek biologi bulu babi Diadema setosum dan Tripneustes gratilla di Kepulauan Spermonde, Sulawesi Selatan. Prosiding Seminar Kelautan Nasional. BPPT, Jakarta.

Tuwo A. 1995. Aspek biologi bulu babi jenis Tripneustes gratilla di Pulau Kapoposan, Dati II Pangkep, Sulawesi Selatan. Oseana 20 (1): 21-29.

Uku J, Björk M. 2005. Productivity aspects of three tropical seagrass species in areas of different nutrient levels in Kenya. Estuar Coast Shelf Sci 63: 407-420.
Unsworth RKF, Cullen LC, Pretty JN, Smith DJ, Bell JJ. 2010. Economic and subsistence values of the standing stocks of seagrass fisheries: Potential benefits of no-fishing marine protected area management. Ocean Coast Manag 53: 218-224.

Uy FA, Pacifico KP, Dy DT. 2000. The distribution of Tripneustes gratilla (Linnaeus) (Echinodermata: Echinoidea) with some notes on Diadema setosum Leske. Proc Int Symp. Mar Biogeogr Evol Southern Hemisphere 2: 707-716.

VaïtilingonD, Rasolofonirina R, Jangoux M. 2003. Feeding preferences, seasonal gut repletion indices, and diel feeding patterns of the sea urchin Tripneustes gratilla (Echinodermata: Echinoidea) on a coastal habitat off Toliara (Madagascar). Mar Biol 3: 451-458.

VaïtilingonD, Rasolofonirina R, Jangoux M. 2005. Reproductive cycle of edible echinoderms from the Southwestern Indian Ocean. I. Tripneustes gratilla L. (Echinoidea, Echinodermata). Western Indian Ocean J Mar Sci 4 (1): 47-60.

Valentine JP, Edgar GJ. 2010. Impact of a population outbreak of the urchin Tripneustes gratilla amongst Lord Howe Island coral communities. J Intl Soc Reef Stud 29: 399-410.

Williams H. 2002. Sea Urchin Fisheries of the World: A Review of their status, management strategies and biology of the principal species. Department of Primary Industries, Water and Environment, Tasmania.

Yusron E. 2006. Keanekaragaman Ekhinodermata di Perairan Morotai Bagian Selatan, Maluku. Oseana 41 (3): 13-20.

Zanre R, Kithi E. 2004. Preliminary sea urchin study and kill report, Watamu. Local Ocean Trust and Watamu Turtle Watch, Watamu, Kenya.

Ziegenhorn MA. 2016. Best dressed test: a study of the covering behavior of the collector urchin Tripneustes gratilla. PLoS ONE 11 (4): e0153581. DOI: 10.1371/journal.pone.0153581

Zigler KS, Lessios HA. 2003. Evolution of bindin in the pantropical sea urchin Tripneustes: comparisons to bindin of other genera. Mol Biol Evol 20: 220-231. 